\title{
METHOD COMPARISON ANALYSIS SIMPLE ADDITIVE WEIGHTING (SAW) WITH WEIGHTED PRODUCT (WP) METHOD IN SUPPORTING THE DECISION TO ACCEPT NEW EMPLOYEES
}

\author{
Idham Ramadhan *, a,1, Umar Zaky b,2 \\ ${ }^{a}$ Informatics, Faculty of Information \& Electrical Technology, University of Technology Yogyakarta, \\ Yogyakarta, Indonesia \\ ${ }^{\mathrm{b}}$ Information System, Faculty of Information \& Electrical Technology, University of Technology Yogyakarta, \\ Yogyakarta, Indonesia

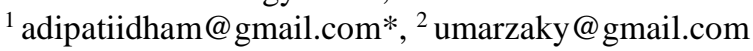

\begin{abstract}
Employee selection is the first step in a company or agency that aims to obtain qualified and competent human resources that will serve and do all the work on an instinct. The process of selection of prospective employees has two decisions that are accepted and rejected. When an agency or company is unable to determine the human resources that fit the required criteria, it will be very detrimental for an agency or company more than the number of prospective employees who register will be troublesome in terms of calculation and determining competent human resources and in accordance with the required criteria. In this case to minimize or solve the problem, the author designed and built a system to help the agencies, especially Gunung Jati Regional Hospital (RSD) in terms of the selection of new employee admissions. The development of this system by analyzing two methods, namely Simple Additive Weighting (SAW) method with Weighted Product (WP) method with the specified criteria. These two methods will be compared to get a good method and relevant to be applied in the selection of new employees at Gunung Jati Hospital so that the human resources received bena-completely in accordance with the needs of the agencies. Analysis is carried out using the accuracy of each method by referring to the original data owned by the institution. The result of saw method conformity or percentage level is $99.959996 \%$ with an accuracy value of $84 \%$ and WP method of $99.959992 \%$ with an accuracy value of $76 \%$. Thus the SAW method is the most relevant method to solve the problem of receiving new employees
\end{abstract}

Keywords: Selection, Prospective Employees, SAW, WP, Gunung Jati Hospital.

\section{INTRODUCTION}

Previous research conducted by Nurjaya, (2017) entitled Comparison of the SAW Method and the WP Method in the Permanent Employee Selection System [1] by involving 5 criteria data, namely age, attendance, discipline, loyalty and achievement along with their respective weight values where the criteria age has a weight value of 2 , attendance 3 , discipline 4 , and loyalty has a weight value of 5 . From the implementation of these two methods, the optimal time results from the two methods are obtained with an average time of 1.6408 seconds for WP and 6.5822 seconds for SAW. Therefore, the research conducted by Nurjaya is a reference for the author to conduct research by implementing the SAW and WP Methods in determining new employees by calculating the effectiveness value of the two methods based on the accuracy value [1]. Both methods will be applied in the selection of new employees at the Gunung Jati Regional Hospital, Cirebon City, as a means for the author to conduct research and data collection.

Gunung Jati regional hospital, Cirebon city is an agency engaged in the regional health sector, which annually selects new employees. It is important for agencies to select new employees who are more selective in order to obtain human resources who are truly qualified and in accordance with what is needed.

The new employee selection process is certainly not an easy matter, especially since the large number of prospective employees will certainly add to the difficulty in the selection process. In addition, there are other problems such as errors in calculating so that the results obtained are less effective and inaccurate which results in mismatching of the criteria for prospective employees needed with the selection results, therefore it is necessary to build a decision support system [2] that will help determine Human Resources (HR), who is suitable to become an employee of RSD Gunung Jati.

Making this system is done by comparing the Weighted Product (WP) method with the Simple Additive Weighting (SAW) method in which the two methods will be the most effective in determining decisions based on the highest percentage value [3]. The system created is a desktop-based system and the criteria used are sourced from the criteria that have been applied in RSD Gunung Jati. This study aims to build a system and analyze which method is more relevant. 


\section{METHOD}

The research method is a procedure used to describe this research running from start to finish for more details of the steps taken are as follows:

\section{A. Field Study}

Field study is the stage at which researchers survey the location to be used as a research site. In this case the selected location is the institution of Gunung Jati Hospital Cirebon city.

\section{B. Identification and Formulation}

At this stage, researchers identify data and appropriateness to what will be used as research, as well as formula the formulation of problems that can be solved with the research that is being done.

\section{Data Collection}

Data collection is the stage at which data is collected to support the research process. In this case the data obtained is data related to the criteria of prospective employees who will be selected to be permanent employees at Gunung Jati Hospital Cirebon. The data obtained is sourced from Gunung jati hospital agency listed in the Staff Recruitment Guide document and it is valid data that has been approved by the agency. The data of prospective employees obtained is 25 people and there are 5 criteria including Writing Test, Interview, MMPI (Psychology), Rikes (Health Test) and Administration (ADM). Based on the Agreement with the agency the name of the prospective employee must be disguised because there is a value that should be a secret agency but because this research requires a value in the form of a number of each criterion so that the value of one of the criteria must be listed on the condition that the name of the prospective employee must be disguised.

\section{System Design}

System planning is the process of designing or designing a structured system in which there are operating steps in the data management process and the process of procedures to support the system created [4]. System design aims to meet the needs of system users and provide a clear picture and complete design.

\section{E. System Implementation}

The implementation of the system is the process of creating the system obtained from the design of the system. System implementation is done using Java and MySQL programming languages that serve as data storage media.

\section{F. Site Testing}

System testing is a process to know the percentage value of the calculation results of saw and WP methods. Testing is done by inputting the data that has been obtained that will continue to be processed by the system by applying calculations using SAW and WP methods.

\section{RESUlTS AND DISCUSSION}

\section{A. Simple Additive Weighting (SAW) Methods}

The SAW method is often also known as the weighted summing method [5]. The basic concept of the SAW method is to look for weighted summation of performance ratings on each alternate on all attributes [6]. The SAW method requires the process of normalizing the decision matrix $(\mathrm{X})$ to a scale that can be compared to all existing alternative ratings. The Matrix Normalization is calculated by (1).

$r_{i j}=\left\{\begin{array}{l}\frac{X_{i j}}{\operatorname{Max}_{i} X_{i j}} \\ \frac{X i j}{\operatorname{Min}_{i} X_{i j}}\end{array}\right.$

Equation (1) is the equation that underlies the calculation of normalization in the calculation of the SAW method. Based on the (1), the description of the symbol is shown in follow:

$r_{i j} \quad$ : normalized performance rating

$x_{i j}:$ the queue value that each criterion has

$\operatorname{Max} X_{i j}$ : the largest value of each criterion

$\operatorname{Min} X_{i j}$ : the smallest value of each criterion

$V_{i}=\sum_{j=1}^{n} W_{j} r_{i j}$

Equation (2) is an equation of the calculation process to get the best alternative test results in the SAW method. Based on the (1), the description of the symbol is shown in follow:

$V_{i} \quad$ : ranking for alternatives

$W_{j}$ : the weight value of each criterion

$r_{i j} \quad$ : normalized performance rating

\section{B. Weighted Product (WP) Methods}

Weighted product method is one of the solutions methods offered to solve the problem of Multi Attribute Decision Making (MADM) [7]. WP method is similar to Weighted Sum (WS) method, only WP method has multiplication of mathematical calculations. WP method is also called dimensional analysis because its mathematical structure eliminates one size. The WP method is a setup of alternative decisions explained in some ways the criteria of the decision. So this method does not need to be normalized. The formula perform weight repair using (3).

$\sum_{i=1}^{n} W_{j}=\frac{W_{j}}{\sum W_{j}}$

Equation (3) is the equation that underlies the calculation of weight normalization in WP method calculation where $\mathrm{W}$ is the initial weight value and is the $W_{-} W_{j}$ of the $j$ index.

Vector S calculation formula in (4) and 
$S_{i}=\prod_{j=1}^{n} X_{i j}{ }^{W_{j}}, i=1,2, \ldots, m$

$V_{i}=\frac{\prod_{j=1}^{n} X_{i j}{ }^{w j}}{\prod_{j=1}^{n}\left(X_{j}\right)^{W_{j}}}$

Equation (4) is an equation to perform the calculation of the force on the WP method. While, the (5) is an equation to perform vector $\mathrm{V}$ calculation process The descriptions of the symbol on these equations are shown in follow:

$\mathrm{S}$ : states alternative preferences analogous to vector $\mathrm{S}$

$\mathrm{X}$ : declares the criteria value

W: states the weight of the criteria

i: stated alternative

$\mathrm{j}$ : states the criteria

$\mathrm{n}$ : states the number of criteria

\section{Discussion}

The research was conducted using 25 data and each data has five criteria and uses two types of methods namely SAW method and WP method where each method has different calculations to get results in the form of ranking. Both methods have the same weight and criteria values. Here are the weight values and criteria used. The detail of the criterias are shown in Table I.

\section{Writing Test}

The value obtained is the value of the writing test results that have been done by prospective employees.

2. Interview

The interview is the final stage of the test where there are 17 questions in the interview test that will be asked of prospective employees.

3. MMPI Test

MMPI test is a similar test such as psychological test is only more complex in its assessment.

4. Health Test

Health Test is a test that aims to get information related to the health of prospective employees who are selected. Because of the results of health tests in the form of qualitative results, researchers conducted a relationship with the agency by converting qualitative results into quantitative.

5. Administrative Test

Administrative tests are tests performed by prospective employees by completing the files both when registering and after they have been accepted. Because the assessment results from administrative tests in the form of qualitative data eat researchers do a deal with agencies to convert the assessment results into quantitative data.

TABLE I. THE WEIGHT VALUES AND CRITERIA USED

\begin{tabular}{|l|l|l|l|}
\hline Criteria & Weights & Various & Description \\
\hline Writing Test & 0.1 & $0-100$ & - \\
\hline Interview & 0.15 & $0-85$ & - \\
\hline MMPI & 0.3 & $0-100$ & - \\
\hline
\end{tabular}

\begin{tabular}{|l|l|l|l|}
\hline Criteria & Weights & Various & Description \\
\hline Health Test & 0.3 & 100 & Recommended \\
\cline { 3 - 4 } & & 0 & Not Recommended \\
\hline Administrative & 0.15 & 100 & Complate \\
\cline { 3 - 4 } & & 0 & Incomplate \\
\hline
\end{tabular}

\section{Flowchart}

\section{System Design}

In the process of designing this system using Data Flow Diagram (DFD), flowchart and Entity Relationship Diagram (ERD) which aims as an overview of how this system will be created. The system design flow to be created is illustrated using the Flowchart contained in Figure 1.

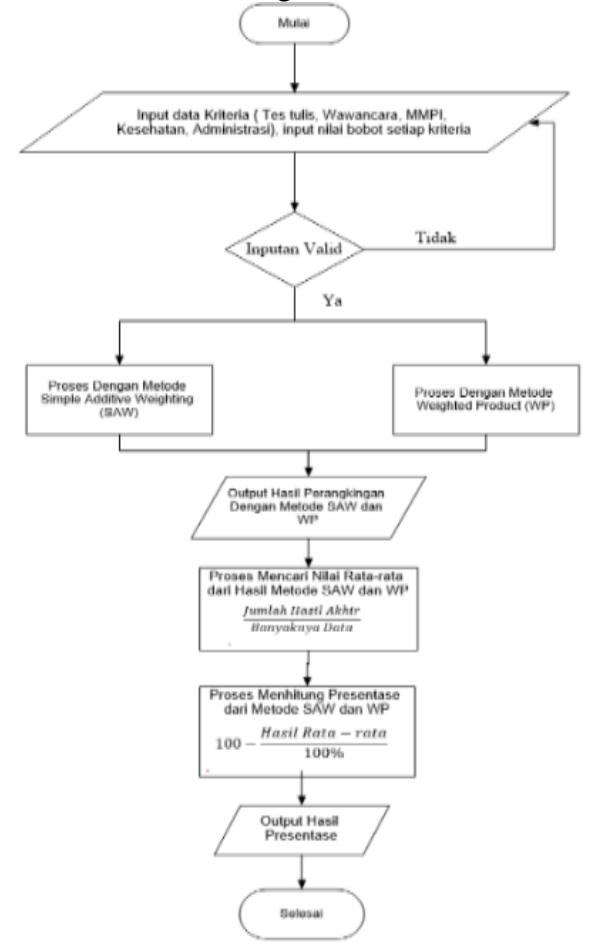

Figure 1. Example of a figure caption. (figure caption)

Figure 1 can be explained that when the user runs the system then before performing the calculation process the user is asked to input the data of the criteria of prospective employees along with the weight value of each criterion. If the input data is valid then the system will proceed to the next process, but if the input data is invalid then the system will return to the initial input process. The next process is that the system will perform the SAW and WP calculation process. After the results of both methods come out then the system will then perform the calculation of the present value and the accuracy value. Then the system will display the final result of the calculation and the process is completed.

\section{SAW Method Flowchart}

The flowchart of the SAW method will describe the process of calculating the criteria data based on the algorithm owned from the SAW method by normalizing the criteria value data by looking for the maximum value of each criterion and weighting 
process. The SAW flow is depicted using the flowchart contained in Figure 2.

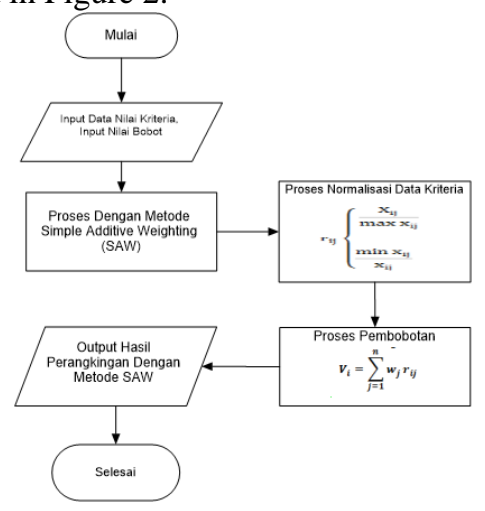

Figure 2. SAW Method Flowchart

3. WP Method Flowchart

The flowchart of the WP method will describe how the data calculation process with the algorithm contained in the WP method. In contrast to the SAW that normalizes the criteria value, in the WP method the weight value to be normalized and the criterion value will be ranked with the resulting value of normalization of the weight then the last weighting will be performed the weighting calculation process to determine the rank. Here is the flowchart of the WP method found in Figure 3.

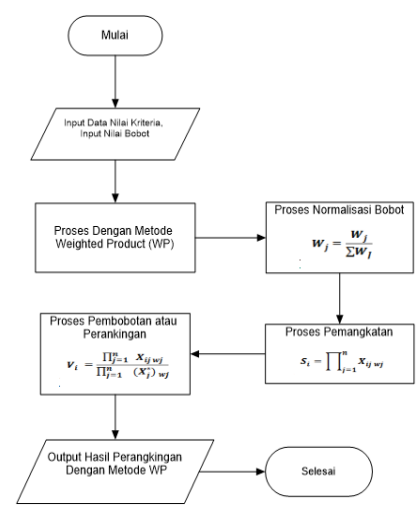

Figure 3. WP Method Flowchart

\section{Precentage Process Flowchart}

The percentage calculation flowchart will describe the flow to get the present value of both methods used. Here is a flowchart of the percentage calculations contained in Figure 4.

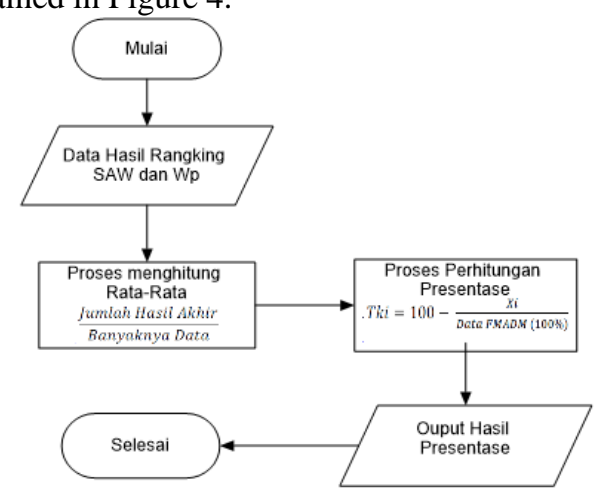

Figure 4. Flowchart Calculation Percentage

\section{E. Program Preview}

\section{Criteria Data Page}

On this page contains data on prospective employees along with criteria obtained after prospective employees perform a number of tests provided by the agency. Here is a view of the Prospective Employee Criteria Data Page found in Figure 5.

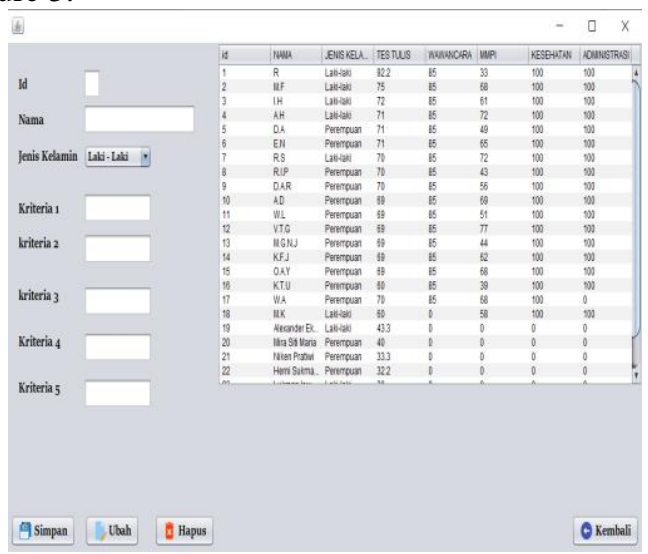

Figure 5. Criterion Data Page

\section{Weight Value Page}

The weight page contains data in the form of weight values from each criterion contained in the system. Here's a look at the Weight Value Page found in Figure 6.

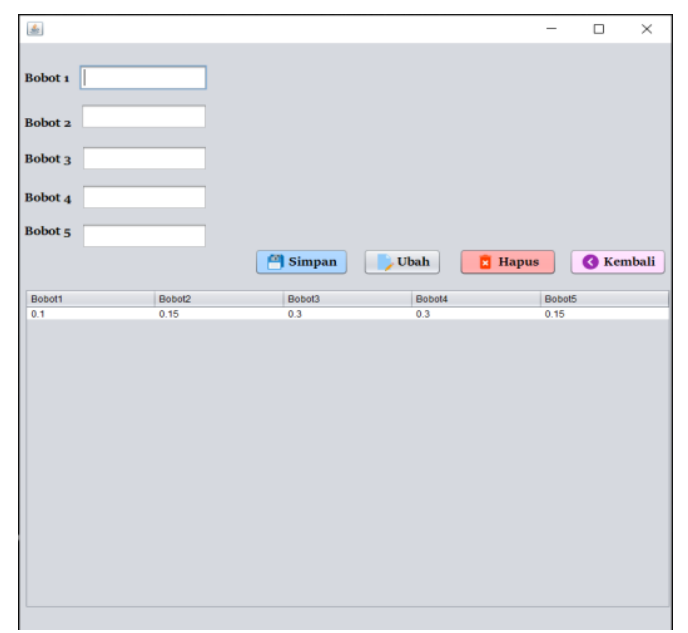

Figure 6. Weight Value Pages

3. Process Page

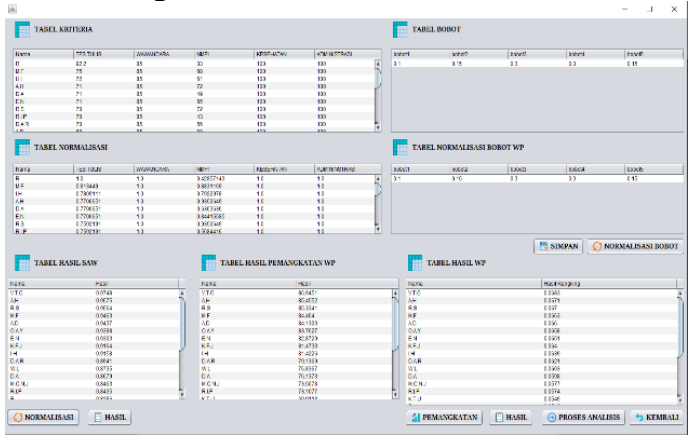

Figure 7. Process Page 
Process page is a page that contains all the calculation data along with the results of the calculation itself. On this page there is also a button to go to the analysis page. Here's a look at the Process Page found in Figure 7.

\section{Analysis Page}

The analysis page contains the results of the analysis calculation in the form of the average value and the result of the percentage value of both methods namely SAW and WP. The following is a display of the analysis page which is shown in Figure 8.

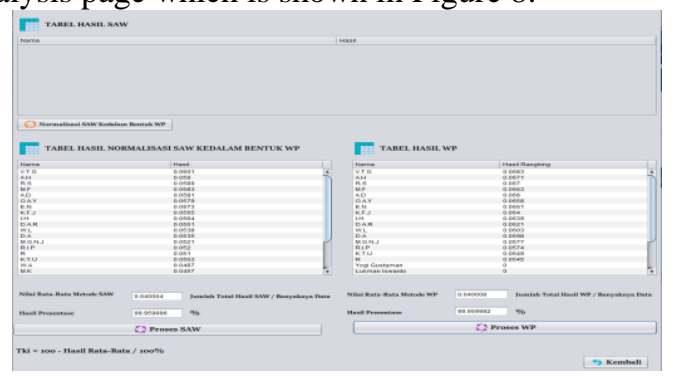

Figure 8. Analysis Page

\section{F. Result}

1. SAW Method Results

Based on the calculations that have been done using the SAW method, the results of the ranking are as follows as found in Table II.

TABLE II. SAW RESULTS TABLE

\begin{tabular}{|l|l|l|}
\hline & Name & Ranking Results \\
\hline$V_{12}$ & V.T.G & 0.9748 \\
\hline$V_{4}$ & H & 0.9575 \\
\hline$V_{7}$ & R.S & 0.9564 \\
\hline$V_{2}$ & (M. & 0.9463 \\
\hline$V_{10}$ & A.D & 0.9437 \\
\hline$V_{15}$ & O.A.Y & 0.9398 \\
\hline$V_{6}$ & E.N & 0.9303 \\
\hline$V_{14}$ & K.F.J & 0.9164 \\
\hline$V_{3}$ & I.H & 0.9158 \\
\hline$V_{9}$ & D.A.R. & 0.8941 \\
\hline$V_{11}$ & W.L & 0.8735 \\
\hline$V_{5}$ & D.A. & 0.8679 \\
\hline$V_{13}$ & M.G.N.J & 0.8463 \\
\hline$V_{8}$ & R.I.P & 0.8435 \\
\hline$V_{1}$ & R & 0.8286 \\
\hline$V_{16}$ & K.T.U & 0.817 \\
\hline$V_{17}$ & W.A & 0.7909 \\
\hline$V_{18}$ & M.K & 0.741 \\
\hline$V_{19}$ & A.E & 0.047 \\
\hline$V_{20}$ & M.S.M & 0.0434 \\
\hline$V_{21}$ & N.P & 0.0361 \\
\hline$V_{22}$ & H.S & 0.0349 \\
\hline$V_{23}$ & L.I & 0.0325 \\
\hline$V_{24}$ & Y.G & 0.029 \\
\hline$V_{25}$ & D.N & 0.0253 \\
\hline
\end{tabular}

Based on the results that have been summarized and from 25 data only 16 prospective employees are received based on the terms and number of employee receipts that have been determined by the agency.

2. WP Method Results
Based on the calculations that have been done using the WP method, the results of the rankings are found in Table III.

TABLE III. WP RESULTS TABLE

\begin{tabular}{|l|l|l|}
\hline & Name & Ranking Results \\
\hline$V_{12}$ & V.T.G & 0.0683 \\
\hline$V_{4}$ & H & 0.0671 \\
\hline$V_{7}$ & R.s & 0.067 \\
\hline$V_{2}$ & M.F & 0.0663 \\
\hline$V_{10}$ & A.D & 0.066 \\
\hline$V_{15}$ & O.A.Y & 0.0658 \\
\hline$V_{6}$ & E.N & 0.0651 \\
\hline$V_{14}$ & K.F.J & 0.064 \\
\hline$V_{3}$ & I.H & 0.0639 \\
\hline$V_{9}$ & D.A.R & 0.0621 \\
\hline$V_{11}$ & W.L & 0.0603 \\
\hline$V_{5}$ & D.A & 0.0598 \\
\hline$V_{13}$ & M.G.N.J & 0.0577 \\
\hline$V_{8}$ & R.I.P & 0.0574 \\
\hline$V_{16}$ & K.T.U & 0.0549 \\
\hline$V_{1}$ & R & 0.0545 \\
\hline$V_{17}$ & W.A & 0 \\
\hline$V_{18}$ & M.K & 0 \\
\hline$V_{19}$ & A.E & 0 \\
\hline$V_{20}$ & M.S.M & 0 \\
\hline$V_{21}$ & N.P & 0 \\
\hline$V_{22}$ & Hs & 0 \\
\hline$V_{23}$ & L.I & 0 \\
\hline$V_{24}$ & Y.G & 0 \\
\hline$V_{25}$ & D.N & 0 \\
\hline & & \\
\hline
\end{tabular}

3. Percentage and Accuracy Analysis Results

Based on the calculation of the SAW method and the WP method obtained, the results of both methods will be used to calculate the level of conformity that claims to the present value. Here are the present results of both methods contained in Table IV.

TABLE IV. PResentage Results TABle

\begin{tabular}{|l|l|l|l|}
\hline Name & $\begin{array}{c}\text { Ranking Results } \\
\text { of SAW } \\
\text { Normalization }\end{array}$ & Name & $\begin{array}{c}\text { Ranking Results } \\
\text { of WP } \\
\text { Normalization }\end{array}$ \\
\hline V.T.G & 0.0601 & V.T.G & 0.0683 \\
\hline A.H & 0.059 & A.H & 0.0671 \\
\hline R.S & 0.0589 & R.S & 0.067 \\
\hline M.F & 0.0583 & M.F & 0.0663 \\
\hline A.D & 0.0581 & A.D & 0.066 \\
\hline O.A.Y & 0.0579 & O.A.Y & 0.0658 \\
\hline E.N & 0.0573 & E.N & 0.0651 \\
\hline K.F.J & 0.0565 & K.F.J & 0.064 \\
\hline I.H & 0.0564 & I.H & 0.0639 \\
\hline D.A.R & 0.0551 & D.A.R & 0.0621 \\
\hline W.L & 0.0538 & W.L & 0.0603 \\
\hline D.A & 0.0535 & D.A & 0.0598 \\
\hline M.G.N.J & 0.0521 & M.G.N.J & 0.0577 \\
\hline R.I.P & 0.052 & R.I.P & 0.0574 \\
\hline R & 0.051 & K.T.U & 0.0549 \\
\hline K.T.U & 0.0503 & R & 0.0545 \\
\hline W.A & 0.0487 & W.A & 0 \\
\hline M.K & 0.0457 & M.K & 0 \\
\hline A.E & 0.0029 & A.E & 0 \\
\hline M.S.M & 0.0027 & M.S.M & 0 \\
\hline N.P & 0.0022 & N.P & 0 \\
\hline H.S & 0.0022 & H.S & 0 \\
\hline L.I & 0.002 & L.I & 0 \\
\hline Y.G & 0.0018 & Y.G & 0 \\
\hline D.N & 0.0016 & D.N & 0 \\
\hline & & & \\
\hline
\end{tabular}


Based on the data in Table IV there are two different sequences of data. Thus, the result can be calculated the percentage value of the data conformity level of the results of both methods. Here are the calculation steps to get the percentage value:

Average $=\frac{\text { sum of the terms }}{\text { number of terms }}$

Average $S A W=\frac{1.0001}{25}=0.040004$

Average $W P=\frac{1.0002}{25}=0.040008$

Next to get the percentage value of both methods is to perform the calculation by using the conformity level formula. Here is the formula used:

$$
\begin{gathered}
T k i=100-\frac{X_{i}}{\text { Data FMADM (100\%) }} \\
S A W=100-\frac{0.040004}{100 \%}=99.959996 \% \\
W P=100-\frac{0.040008}{100 \%}=99.959992 \%
\end{gathered}
$$

TABLE V. ACCURACy Results TABle

\begin{tabular}{|l|l|l|l|l|l|l|l|}
\hline \multirow{2}{*}{ Name } & SAW Results by & \multirow{2}{*}{ Name } & \multicolumn{2}{|c|}{ WP Manual Results by } & \multirow{2}{*}{ Name } & \multirow{2}{*}{ Agency Result } \\
\cline { 2 - 3 } & System & Manual & & System & \multicolumn{1}{|c|}{ Manual } & & \\
\hline V.T.G & 0.9748 & 0.9748 & V.T.G & 0.0683 & 0.0682 & V.T.G & 87.75 \\
\hline A.H & 0.9575 & 0.9575 & A.H & 0.0671 & 0.0671 & A.H & 86.45 \\
\hline R.S & 0.9564 & 0.9564 & R.S & 0.067 & 0.0669 & R.S & 86.35 \\
\hline M.F & 0.9463 & 0.9463 & M.F & 0.0663 & 0.0663 & A.D & 86.25 \\
\hline A.D & 0.9437 & 0.9437 & A.D & 0.066 & 0.066 & M.F & 85.65 \\
\hline O.A.Y & 0.9398 & 0.9398 & O.A.Y & 0.0658 & 0.0657 & O.A.Y & 85.05 \\
\hline E.N & 0.9303 & 0.9302 & E.N & 0.0651 & 0.065 & E.N & 84.35 \\
\hline K.F.J & 0.9164 & 0.9164 & K.F.J & 0.064 & 0.0639 & I.H & 83.25 \\
\hline I.H & 0.9158 & 0.9158 & I.H & 0.0639 & 0.0639 & K.F.J & 83.25 \\
\hline D.A.R & 0.8941 & 0.8941 & D.A.R & 0.0621 & 0.0621 & D.A.R & 81.55 \\
\hline W.L & 0.8735 & 0.8735 & W.L & 0.0803 & 0.0603 & W.L & 79.95 \\
\hline D.A & 0.8679 & 0.8679 & D.A & 0.0598 & 0.0597 & D.A & 79.55 \\
\hline M.G.N.J & 0.8463 & 0.8463 & M.G.N.J & 0.0577 & 0.0577 & M.G.N.J & 77.85 \\
\hline R.I.P & 0.8435 & 0.8434 & R.I.P & 0.0574 & 0.0573 & R.I.P & 77.65 \\
\hline R & 0.8286 & 0.8286 & R & 0.0549 & 0.0548 & R & 76.87 \\
\hline K.T.U & 0.817 & 0.817 & K.T.U & 0.0545 & 0.0544 & K.T.U & 75.45 \\
\hline W.A & 0.7909 & 0.7909 & W.A & 0 & 0 & W.A & 70.15 \\
\hline M.K & 0.741 & 0.741 & M.K & 0 & 0 & M.K & 68.4 \\
\hline A.E & 0.047 & 0.047 & A.E & 0 & 0 & A.E & 4.33 \\
\hline M.S.M & 0.0434 & 0.0434 & M.S.M & 0 & 0 & M.S.M & 4 \\
\hline N.P & 0.0361 & 0.0361 & N.P & 0 & 0 & N.P & 3.33 \\
\hline H.S & 0.0349 & 0.0349 & H.S & 0 & 0 & H.S & 3.22 \\
\hline L.I & 0.0325 & 0.0325 & L.I & 0 & 0 & L.I & 3 \\
\hline Y.G & 0.029 & 0.029 & Y.G & 0 & & Y.G & 2.67 \\
\hline D.N & 0.0253 & 0.0253 & D.N & 0 & & D.N & 2.33 \\
\hline & & & & & & \\
\hline
\end{tabular}

4. Quotation and References

Research by Mulyani, E. D. S. et al., (2019), with the title Comparison of Decision Support System Using SAW and WP Methods in Lending [7]. The research discussed the effectiveness of two methods, namely between Simple Additive Weighting (SAW) and Weighted Product (WP) method in determining lending. In his research obtained accuracy from each method by $97.274 \%$ for SAW and $99.8000 \%$ for WP.

Research by Supiyan, D., (2019), titled Match SAW, WP and Topsis Methods in Determining Financing of BMT EL-RAUSHAN. In his research of
Based on the results contained in Table $\mathrm{V}$, the comparison between the SAW method and the WP method there is a difference in the sequence of data results of system rankings and paper manuals against manual ranking data from agencies. To obtain the accuracy value, the equation of the formula obtained from the material compiled by Abidin, T. F., (2012) is as found in (8).

$$
\begin{aligned}
& \text { Accuracy }=\frac{\text { sum of true data }}{\text { total }} * 100 \% \\
& \text { Accuracy SAW }=\frac{21}{25} * 100 \%=84 \% \\
& \text { Accuracy } W P=\frac{19}{25} * 100 \%=76 \%
\end{aligned}
$$

Based on the results of the above accuracy calculation, in this study obtained accuracy values from both methods of $84 \%$ for SAW method while $76 \%$ for WP method. 
Weighting (SAW) and Weighted Product (WP) Methods for Hospital Assessment. In his research, the best alternative results were ranked 11th out of the two methods used [9].

Research by Sulistiyaningsih, F. et al., (2018), titled Comparison of Simple Assessment Methods and Combination of SPK-360 Degrees in Janitor Performance Assessment. In this study discussed related to determining the best performance of the janitors of Banyumas Regional Unit Hospital (HOSPITAL) using 360 degree method and determination of criteria with Analytical Hierarchy Process (AHP) method. With the system is expected to determine the janitor with proper performance [10].

\section{Conclusion}

Based on the results of the study and the results of the test system, in this case the authors can draw conclusions related to the analysis system comparison of simple additive weighting (SAW) method with Weighted Product (WP) method in the selection of new employee admissions are as follows:

1. Based on the research done to obtain efficiency and effectiveness, percentage testing and accuracy testing so that the results of the test show which method is more effective and efficient is the SAW method.

2. Based on the results of the test starting from the calculation of normalization, generation, and determining the rank obtained the largest percentage value of $99.959996 \%$ for method SAW and $99.959992 \%$ for WP method with a difference of 0.000004 between the two methods.

3. Based on the test accuracy value obtained an accuracy value of $84 \%$ for the SAW method and $76 \%$ for the WP method, thus it can be stated that the SAW method has a greater accuracy value compared to the WP method.

\section{REFERENCES}

[1] N. Nurjaya, "Perbandingan Metode Saw Dengan Metode WP Pada Sistem Seleksi Karyawan Tetap," SNTIBD, vol. 2, no. 1, pp. 369-372, 2017.

[2] Kusrini, "Konsep dan Aplikasi Sistem Pendukung Keputusan." Andi Publisher, 2007.

[3] Y. Melia, "Multi attribute decision making using simple additive weighting and weighted product in investment," Int. Acad. J. Bus. Manag., vol. 3, no. 7, pp. 1-15, 2016.

[4] M. Yazdani, P. Zarate, A. Coulibaly, and E. K. Zavadskas, "A group decision making support system in logistics and supply chain management," Expert Syst. Appl., vol. 88, pp. 376-392, Dec. 2017, doi: 10.1016/j.eswa.2017.07.014.

[5] S. Kusumadewi, S. Hartati, A. Harjoko, and R. Wardoyo, Fuzzy Multi-Attribute Decision Making (Fuzzy MADM). 2006.

[6] M. N. H. Alvianto and S. Saifullah, "Sistem Pendukung Keputusan Pemilihan Cafe di Yogyakarta dengan Menggunakan Metode Simple Additive Weighting (SAW), 'J. Innov. Inf. Technol. Appl., vol. 2, no. 01, pp. 47-55, Jun. 2020, doi: 10.35970/jinita.v2i01.187.

[7] E. D. Sri Mulyani, “Analisis Perbandingan Sistem Pendukung Keputusan Menggunakan Metode SAW Dengan WP Dalam Pemberian Pinjaman," CogITo Smart J., vol. 5, no. 2, p. 239, Dec. 2019, doi: 10.31154/cogito.v5i2.151.239-251.

[8] H. Rizqifaluthi, Rahmawati, F. Amri, and M. A. Yaqin, "Optimasi Penjadwalan Kegiatan Sekolah Menggunakan Metode Weighted Product (WP)," J. Vocat. Tek. Elektron. dan Inform., vol. 8, no. 1, pp. 1-6, 2020.

[9] P. P. Andika, M. Gumanti, and S. Mukodimah, "Perbandingan Metode Simple Additive Weighting (SAW) dan Weighted Product (WP) Untuk Penilaian Rumah Sehat," JTKSI (Jurnal Teknol. Komput. dan Sist. Informasi), vol. 3, no. 2, pp. 93-99, 2019.

[10] E. Sulistiyaningsih, Y. Suyanto, and S. Priyanta, "Perbandingan Metode Penilaian Sederhana dan Kombinasi SPK-360 Derajat dalam Penilaian Kinerja Petugas Kebersihan," BIMIPA, vol. 25, no. 2, pp. 191-203, 2018. 